\title{
Report from the Eighth Session of the WHO FCTC Conference of the Parties
}

\author{
Ryan Forrest \\ Framework Convention Alliance for Tobacco Control, Canada
}

\begin{abstract}
Discussions at the FCTC COP8 in October 2018 focused on strengthening implementation of the treaty in countries around the world. Key decisions included the adoption of a new Global Strategy for tobacco control, which identifies priorities for work at the global and national levels until 2025. Discussions also highlighted challenges to future progress, including the tobacco industry's continued efforts to undermine COP negotiations and severe resource constraints.
\end{abstract}

KEY WORDS: WHO Framework Convention on Tobacco Control, COP8, tobacco control.

ADDRESS FOR CORRESPONDENCE: Ryan Forrest, Framework Convention Alliance for Tobacco Control, Canada, e-mail: forrestr@fctc.org

During 1-6 October 2018, the international tobacco control community gathered at the eighth session of the FCTC Conference of the Parties (COP) to review progress implementing the global tobacco treaty - the WHO Framework Convention on Tobacco Control (FCTC) - and to commit to further action to combat the tobacco epidemic.

Until recently, discussions at the FCTC COP had been largely technical in nature. For the first decade of the treaty's life COP discussions were focused on negotiating FCTC implementation guidelines, which provide detailed, best-practice policy guidance to governments on a number of the treaty's key provisions. With much of this work now complete, a new kind of COP session has begun to take shape, one focused on addressing questions of why the FCTC's detailed policy guidance has not been adequately implemented in countries around the world.

A report released by the FCTC Secretariat at COP8 [1] highlights just how far we still have to go. The Global Progress Report on FCTC implementation notes that just $13 \%$ of countries that are party to the treaty are on track to meet agreed commitments to reduce tobacco use prevalence by $30 \%$ by 2025 . The report also notes that in the past two years $9 \%$ of parties to the treaty (Parties) saw increases in tobacco use in their countries, while $60 \%$ identified specific gaps in implementation of the treaty.
Against this backdrop, the Parties discussed ways forward for tobacco control. Arguably the most important outcome of the week was the adoption of the Global Strategy to Accelerate Tobacco Control [2] - the first strategic plan for the FCTC. The Strategy represents an agreement by all Parties on where they would like to be by 2025 , and how they are going to get there. It identifies clear priorities for work under the Convention, including developing and costing national tobacco control plans, implementing price and tax measures (Article 6), and implementing the time-bound measures of the Convention (Articles 8, 11 and 13), all with the ambitious objective of reducing tobacco use prevalence by $30 \%$ by 2025. The Strategy is intended to guide Parties' national efforts, and to inform the work of other relevant stakeholders.

In adopting this Strategy, the COP also agreed to set up a peer-led FCTC Implementation Review Mechanism by 2020. Such mechanisms are common under human rights and environmental treaties [3], where expert committees review Parties' progress in fulfilling their obligations under the treaty. Civil society advocates have pointed to the establishment of such a mechanism for the FCTC as an important tool to shed more light on Parties' experiences implementing the FCTC - both successes and challenges - to better understand Parties' needs for support, and to more clearly identify priorities 
for resource mobilisation [3]. A number of pilot projects for this review process will take place before COP9 in 2020, which will provide an opportunity for Parties to adapt the review process to best suit their needs.

Negotiations also focused on addressing new and emerging issues in tobacco control. Governments re-affirmed that Heated Tobacco Products (such as IQOS and Glo) are indeed tobacco products and that, as such, are subject to regulation under the FCTC [4]. Parties also discussed the changing modern media landscape and its implications for cross-border tobacco advertising and agreed to develop additional policy guidance on this issue through an addendum to the existing FCTC Article 13 guidelines [5].

Throughout the discussions, tobacco industry interference threatened to derail progress. A small group of industry-influenced countries worked in a coordinated manner to weaken the text of decisions and delay consensus on several key issues, in a manner closely resembling what was witnessed at COP7 [6].

To address this challenge, COP8 adopted a number of operational policies that will help to increase the transparency of future COP sessions. These include requirements for each Party to declare that they have observed the Convention's conflict-of-interest policy (Article 5.3) in selecting their delegation to the COP [7], as well as policies that will make it easier for representatives of the media to attend COP sessions, report on negotiations, and shed light on tobacco industry tactics to undermine progress [7].

A final, important topic of discussion at COP8 was the question of how to finance treaty operations and broader tobacco control efforts. A proposal to increase the size of the treaty's operating budget was met with resistance from Parties, who opted instead for a zero nominal increase in the COP budget [8]. Despite growth in the number of Parties to the treaty over the past 10 years, the COP budget has remained virtually unchanged. Moreover, the recent entry into force of the Protocol to Eliminate Illicit Trade has placed additional demands on the COP's limited resources. The result is that much of the core work under the treaty, including work to support Parties' efforts to implement the treaty, relies on external, yet-to-be-mobilised funding.

While it is possible that the new Global Strategy may help to ensure a more effective allocation of existing resources in future, it is clear that substantially more funding is needed to enable meaningful progress. High-income country Parties must step up to the plate to provide international assistance for FCTC implementation, following the example of Parties such as the United Kingdom, Canada, Norway, the European Union, Panama, and others.

COP8 marked an important milestone for global tobacco control through the adoption of the Global Strategy. However, much work remains to be done to trans- late this document into real progress. Parties, observers, and other relevant stakeholders must work in the coming months and years to take action in line with its goals and objectives, and to mobilise substantial additional funding for this work.

\section{DISCLOSURE}

The author reports no conflict of interest.

\section{References}

1. 2018 Global progress report on implementation of the WHO Framework Convention on Tobacco Control. World Health Organization, Geneva 2018. Available from: https://www.who.int/ fctc/reporting/WHO-FCTC-2018_global_progress_report.pdf (accessed: 15 October 2018).

2. WHO Framework Convention on Tobacco Control Conference of the Parties, Eighth Session. Measures to strengthen implementation of the Convention through coordination and cooperation. 6 October 2018. FCTC/COP8(16). Available from: https://www. who.int/fctc/cop/sessions/cop8/FCTC_COP8(16).pdf (accessed: 15 October 2018).

3. Framework Convention Alliance. Reporting Arrangements under the WHO FCTC. Briefing Paper of the Seventh Session of the WHO Framework Convention on Tobacco Control Conference of the Parties. August 2016. Available from: https://www.fctc.org/ wp-content/uploads/2016/09/FCA_COP7Brief_ReportingArrangements.pdf (accessed: 15 October 2018).

4. WHO Framework Convention on Tobacco Control Conference of the Parties, Eighth Session. Novel and Emerging Tobacco Products. 6 October 2018. FCTC/COP8(22). Available from: https:// www.who.int/fctc/cop/sessions/cop8/FCTC__COP8(22).pdf (accessed: 15 October 2018).

5. WHO Framework Convention on Tobacco Control Conference of the Parties, Eighth Session. Novel and Emerging Tobacco Products. 6 October 2018. FCTC/COP8(17). Available from: https:// www.who.int/fctc/cop/sessions/cop8/FCTC__COP8(17).pdf (accessed: 15 October 2018).

6. Drope J, Stoklosa M. Report from the WHO FCTC Seventh Session of the Conference of the Parties. J Health Inequal 2016; 2: $128-129$

7. WHO Framework Convention on Tobacco Control Conference of the Parties, Eighth Session. Maximizing transparency of delegations from Parties and observers to the Conference of the Parties, its subsidiary bodies and other WHO FCTC Meetings. 6 October 2018. FCTC/COP8(12). Available from: https:// www.who.int/fctc/cop/sessions/cop8/FCTC__COP8(12).pdf (accessed: 15 October 2018).

8. WHO Framework Convention on Tobacco Control Conference of the Parties, Eighth Session. Workplan and Budget for the Financial Period 2020-2021. 6 October 2018. FCTC/COP8(10). Available from: https://www.who.int/fctc/cop/sessions/cop8/FCTC COP8(10).pdf (accessed: 15 October 2018). 